\title{
Influences of suspended sediments on the ecosystem in Lake Michigan: a 3-D coupled bio-physical modeling experiment
}

\author{
Rubao Ji a, Changsheng Chen ${ }^{\text {a,* }}$, Judith Wells Budd ${ }^{\mathrm{b}}$, David J. Schwab ${ }^{\mathrm{c}}$, \\ Dmitry Beletsky ${ }^{\mathrm{c}}$, Gary L. Fahnenstiel ${ }^{\mathrm{d}}$, Thomas H. Johengen ${ }^{\mathrm{c}}$, \\ Henry Vanderploeg ${ }^{\mathrm{c}}$, Brian Eadie ${ }^{\mathrm{c}}$, James Cotner ${ }^{\mathrm{e}}$, Wayne Gardner ${ }^{\mathrm{f}}$, \\ Marie Bundy ${ }^{g}$ \\ a Department of Marine Sciences, The University of Georgia, Athens, GA 30602, USA \\ b Department of Geological Engineering and Sciences, Michigan Technological University, Houghton, MI 49931, USA \\ c NOAA/GLERL, 2205 Commonwealth Boulevard, Ann Arbor, MI 48105-2945, USA \\ d The Lake Michigan Field Station, NOAA/GLERL, 1431 Beach Street, Muskegon, MI 49441, USA \\ e Department of Ecology Evolution and Behavior, University of Minnesota, St. Paul, MN 55108, USA \\ ${ }^{\mathrm{f}}$ Department of Marine Sciences, University of Texas at Austin, Austin, TX 78712, USA \\ ${ }^{g}$ Academy of Natural Sciences, Estuarine Research Center, St. Leonard, MD 20005, USA
}

Received 24 January 2001; received in revised form 29 January 2002; accepted 29 January 2002

\begin{abstract}
The influence of suspended sediments on the Lake Michigan ecosystem was examined using a 3-dimensional (3-D) coupled biological and physical model developed by Chen et al. (part I). The model was driven by the realistic meteorological forces observed in March 1998, with daily inputs of suspended sediment concentration that were derived from temporally and spatially interpolated satellite imagery. The model results show the significant impact of a seasonally recurring coastal resuspension plume on the spatial and temporal variation of the nutrients and plankton in southern Lake Michigan. The plume-released nutrients played an essential role in maintaining the nutrient level in the lake. Although the growth of phytoplankton in the plume depended on the availability of nutrients and light, the offshore decrease in phytoplankton biomass still satisfied the Sverdrup's relationship. Cross-shore fluxes of nutrients and phytoplankton were controlled by episodic wind events with a period of $\approx 5-7$ days: offshore during southward winds and onshore during northward winds. The flux estimates for biological variables suggest that the microbial food web is a key contributor to secondary production in southern Lake Michigan and the lower trophic level food web system could be dynamically divided into two decoupled loops: (1) detritus-bacteria-microzooplankton-large zooplankton; and (2) nutrient-phytoplankton-detritus. The model-predicted spatial distributions of nutrients and phytoplankton were in reasonable agreement with observations taken during the 1998 EEGLE interdisciplinary cruises, suggesting that the model was sufficiently robust to capture the basic characteristics of the Lake Michigan ecosystem during the plume event. (C) 2002 Published by Elsevier Science B.V.
\end{abstract}

Keywords: Ecosystem; Coupled biological and physical model; Phytoplankton growth; Microbial processes; Lake Michigan

* Corresponding author. Tel.: + 1-508-910-6388; fax: + 1-508-910-6371.

E-mail address: c1chen@umassd.edu (C. Chen). 


\section{Introduction}

Satellite imagery in the visible wavelength band reveals the episodic occurrences of the highly reflective coastal plume during early spring in southern Lake Michigan (Mortimer, 1988; Eadie et al., 1996; Warrington, 2001). This plume, which is $\approx 10 \mathrm{~km}$ wide and $100 \mathrm{~km}$ long, appears along the southern shoreline as a result of (1) intermittent shoreline erosion; (2) wave-driven resuspension of temporary sediment deposits; and (3) current convergence in the coastal region (Lineback et al., 1971; Edgington and Robbins, 1973; Mortimer, 1988). It generally appears in March and disappears in late April, as seasonal stratification develops. One plume, for example, appeared around the 9th March, 1998, during a strong southward wind event, lasted for $\approx 1$ week and then diminished over March 15-17, when the wind turned northward (Fig. 1). Episodic resuspension occurred again on March 18 during a sustained southward wind of $10 \mathrm{~ms}$. In total, the 1998 plume period lasted almost 2 months and disappeared in late April when the lake began to be stratified. During the plume period, both physical and biological variables were vertically well mixed in the lake.

The March 1998 plume was usually characterized by a low light level but high nutrient concentrations. Because of light limitation in the plume, no significant cross-shore variation of the phytoplankton concentration was detected, especially over a time scale of 5-7 days. A higher density of bacteria was found during the plume event, which was believed to be a result of high decomposition from the detritus pool associated with sediment resuspension (Cotner et al., 1999; Chen et al., 2002). The existence of high bacterial abundances implies that the microbial food web probably could supply the energy required for the growth of microzooplankton. Since the phytoplankton within the plume showed no significant growth during the period, the episodic plume appeared to have an influence on secondary rather than on primary production. Because of the lack of 3-D modeling studies, it is still unclear what is the role of the sediment resuspension in biological interaction within the lower trophic level food web ecosystem in Lake Michigan.
The offshore transport of nutrients and phytoplankton associated with plume materials was closely related to the episodic meteorological forcings. Strong southward winds tended to generate large waves and southward currents along the east and west coasts of the southern basin. These two coastal currents converge in the southeastern portion of the lake to produce an offshore flow of suspended sediment somewhere along the southern shore (Fig. 2) (Csanady, 1982; Schwab, 1983; Mortimer, 1988; Eadie et al., 1996; Schwab et al., 2000). This classic wind-induced circulation pattern was derived based on a steady wind forcing. Therefore, it is unclear how time-dependent winds affect the offshore, cross-plume net fluxes of water property, nutrients and phytoplankton.

A satellite-derived chlorophyll- $a$ map from the sea-viewing wide field-of-view sensor (SeaWiFS) obtained on March 24 during the plume event showed a donut-shaped distribution pattern in the interior of southern Lake Michigan offshore of the plume (Fig. 3; Warrington, 2001; Budd et al., 2001). Note that chlorophyll concentration was elevated on March 24 in the offshore near Muskegon and appeared to circulate cyclonically in the interior. A SeaWiFS sediment map (as the SeaWiFS remote sensing reflectance at $555 \mathrm{~nm}$, Rrs(555)) showed a high sediment concentration in the region of the offshore transport (Fig. 1). The offshore donut-shaped chlorophyll zone (not associated with the plume) was of interest to observational biologists because it was not seen on the SeaWiFS sediment maps. This offshore-enhanced donut-shape chlorophyll- $a$ concentration was also detected from the March 1998 observational data from a vertically tow-yoed plankton survey system (PSS).

The average value of the satellite-derived chlorophyll- $a$ concentrations in the southern Lake Michigan over March 1998 was $1.96 \mu \mathrm{g} \mathrm{1}^{-1}$ with a S.D. of $0.3 \mu \mathrm{g}^{-1}$ (Budd et al., 2000). The cross-shore variation of the satellite-derived chlorophyll- $a$ concentration was a little larger than the uncertainty value estimated by the S.D. Therefore, the donut-shaped structure of chlorophyll- $a$ concentration detected in southern Lake Michigan was a robust feature. 
The detection of the donut-like distribution of chlorophyll- $a$ concentration in southern Lake Michigan raises some fundamental questions about the ecosystem dynamics during the winter to spring transition in southern Lake Michigan. What factors controlled the spatial distribution of
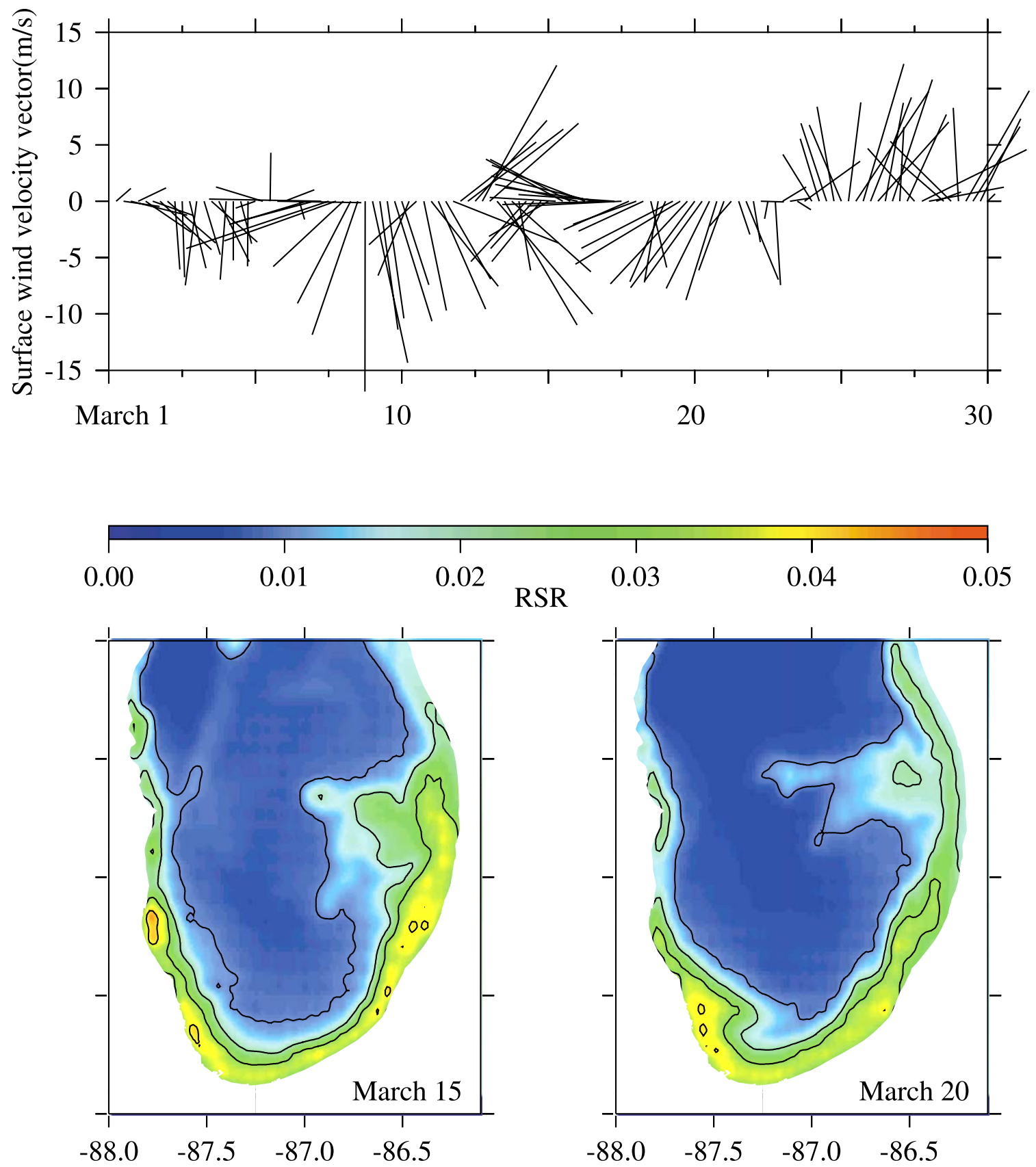

Fig. 1. Time series of surface wind velocity vectors taken at center of lake basin (shown in Fig. 2) and spatial distributions of percent remote-sensing reflectance (RSR) taken on March 15 and 20, 1998 in southern Lake Michigan. 


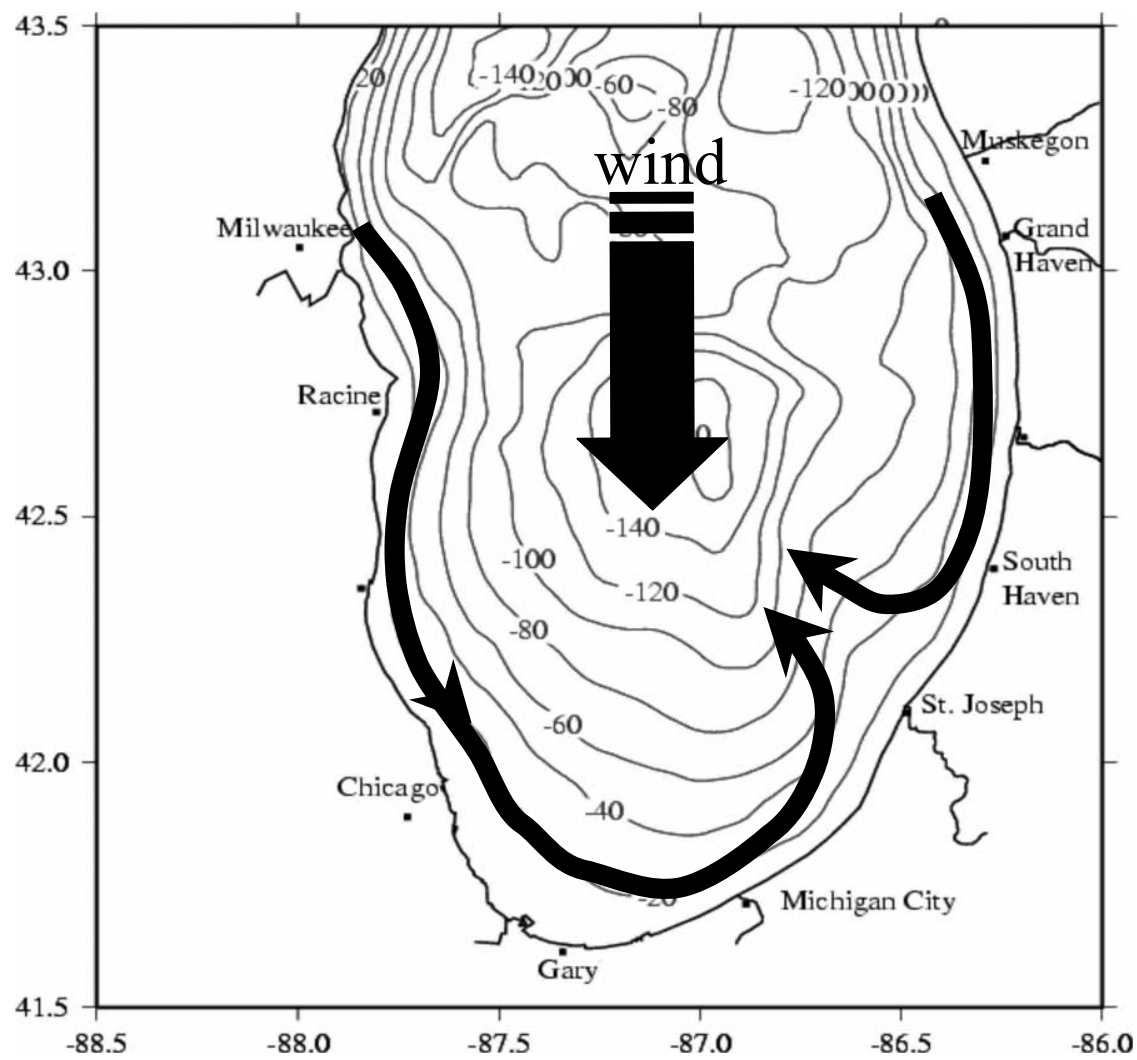

Fig. 2. Schematic of the wind (southward)-induced circulation pattern in southern Lake Michigan.

the plankton at this time? Is the Sverdrup relationship still valid in Lake Michigan? Assuming there was nutrient release from the suspended sediment during the plume period, what mechanisms promoted offshore phytoplankton growth in the interior? Finally, how did the offshore donut-shaped structure of the chlorophyll- $a$ form in an environment where vertical mixing is highly energetic?

As part of the observational component of the US NSF/NOAA funded Episodic Event-Great Lakes Experiment (EEGLE) program, a series of interdisciplinary field measurements were conducted during the March 1998 plume event in southern Lake Michigan. Biological measurements were focused on three cross-shore transects near the St. Joseph, Muskegon and Gary (Fig. 4), where water samples and continuous data from the two-yoed PSS were taken over March 16-19.
Schwab and Beletsky at the NOAA Great Lake Environmental Research Laboratory (GLERL) have used the Princeton ocean model (POM) to simulate temperature and currents in Lake Michigan for the March 1998 plume event. In this paper, we attempt to use our 3-D coupled biological and physical model (Chen et al., 2002) to examine the influence of suspended sediment on the lower trophic food web ecosystem in southern Lake Michigan. Our studies are focused on the spatial distribution of nutrients and phytoplankton and on the role/contribution of the microbial food web in/to the energy flux in the lower trophic level food web system.

The remaining sections of this paper are organized as follows: in Section 2, the 3-D version of the coupled biological and physical model is described, including the method used to incorporate the satellite imagery into the model. In Section 3, 
the model results are presented and model-data comparisons are given. In Section 4, the key factors controlling the spatial distribution of the phytoplankton inside and outside the plume are examined. A summary is given in Section 5 .

\section{Chlorophyll a $(\mu \mathrm{g} / \mathrm{l})$}

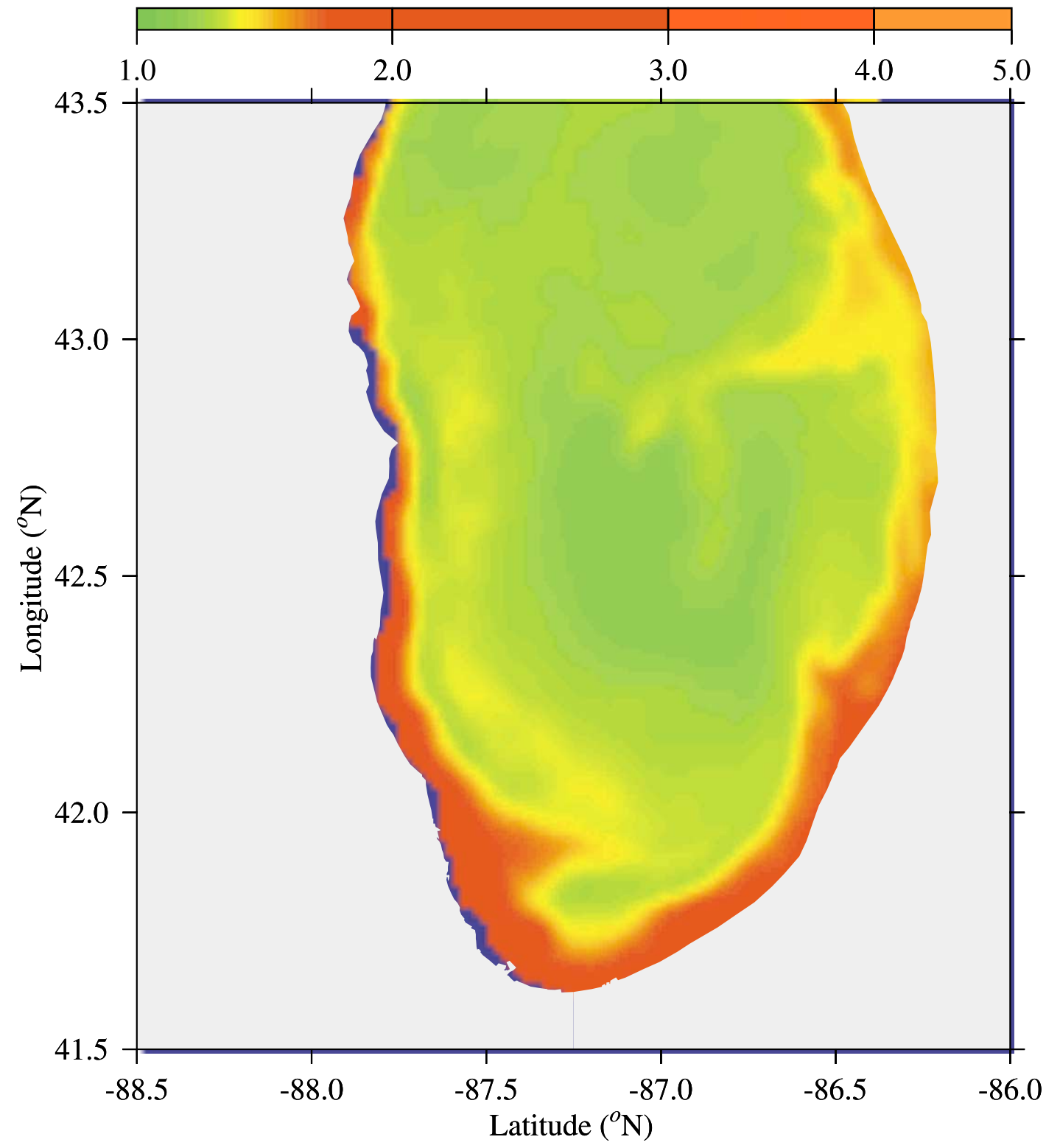

Fig. 3. The surface distribution of the satellite-derived chlorophyll- $a$ concentration in southern Lake Michigan on March 25, 1998. The image was plotted using the values converted exponentially from the chlorophyll- $a$ concentration with the form of $e^{c h l / 3}$, where $c h l\left(\mu \mathrm{g}^{-1}\right)$ was the chlorophyll- $a$ concentration. 


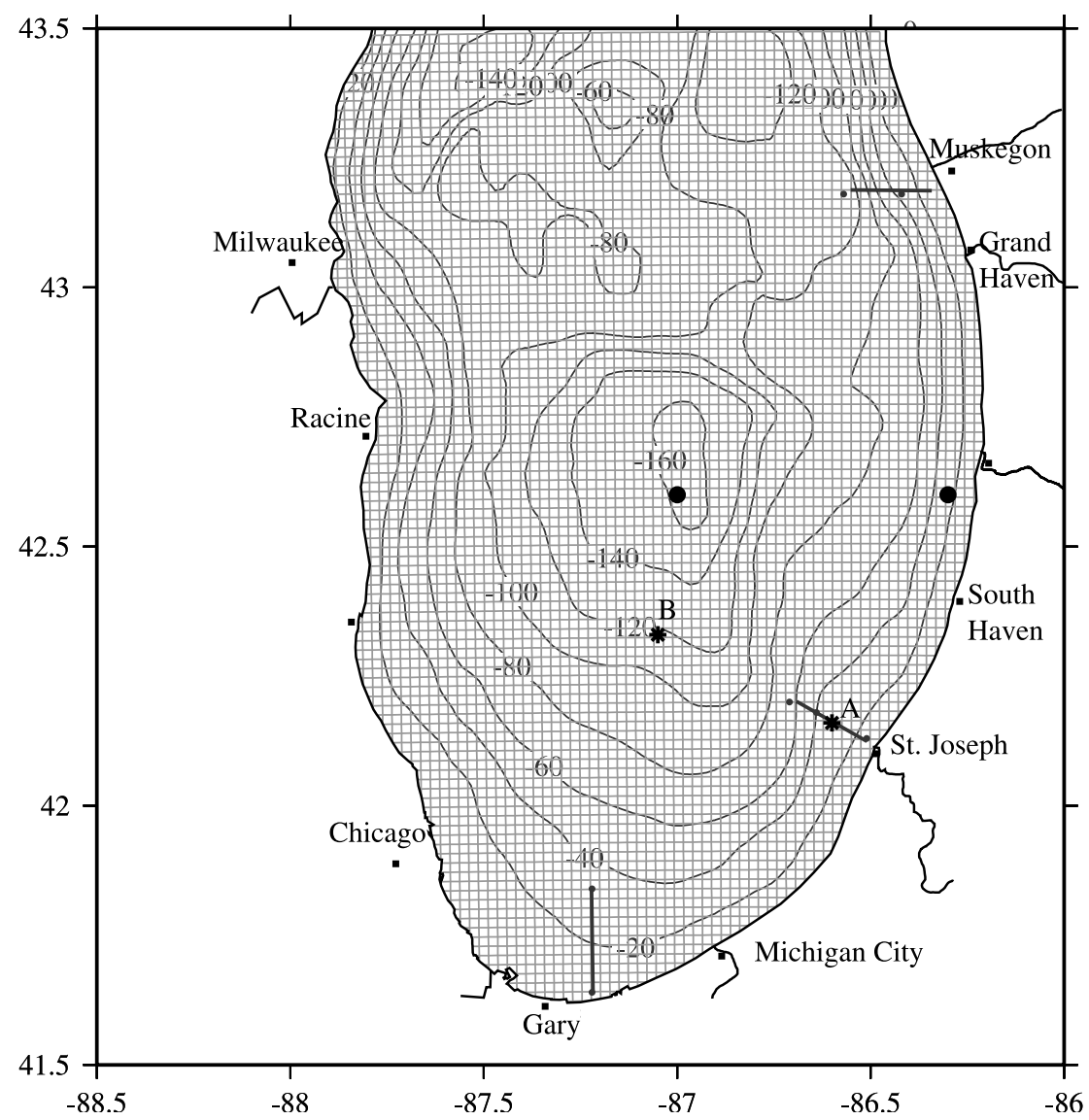

Fig. 4. Bathymetry (thin solid curved lines) and model grids in southern Lake Michigan. Heavy solid straight lines represent the cross-isobath transects near the Muskegon, St. Joseph and Gary. Heavy solid curved lines indicate the river path terminated around the Lake. Asterisks are the locations of sites A and B used to estimate the flux among biological variables in the food web.

\section{The coupled biological and physical model}

The model experiments were conducted using the 3-D coupled biological and physical model of Lake Michigan developed by Chen et al. (2002). Since our studies were focused on the plume event in early spring, where silicon was not a limiting factor for phytoplankton growth, we removed silicon from the biological model and made a purely phosphorus-controlled lower trophic level food web system with seven state variables (Fig. $5)$. The governing equations for the modified biological model are given as

$$
\begin{aligned}
& \frac{d P_{\mathrm{L}}}{d t}-\frac{\partial}{\partial z}\left(A_{\mathrm{h}} \frac{\partial P_{\mathrm{L}}}{\partial z}\right) \\
& =\mathrm{L} P(\text { uptake })-\mathrm{L} P \text { (mortality) }-\mathrm{L} Z \mathrm{~L} P \text { (grazing) } \\
& \quad-\mathrm{L} P(\text { sinking }) \\
& \frac{d P_{\mathrm{S}}}{d t}-\frac{\partial}{\partial z}\left(A_{\mathrm{h}} \frac{\partial P_{\mathrm{S}}}{\partial z}\right) \\
& =\mathrm{S} P(\text { uptake })-\mathrm{S} P \text { (mortality) }-\mathrm{S} Z \mathrm{~S} P(\text { grazing) }
\end{aligned}
$$

$$
\frac{d Z_{\mathrm{L}}}{d t}-\frac{\partial}{\partial z}\left(A_{\mathrm{h}} \frac{\partial Z_{\mathrm{L}}}{\partial z}\right)
$$




$$
\begin{aligned}
& =\varepsilon^{Z_{\mathrm{L}}} \mathrm{L} Z \mathrm{~L} P(\text { grazing })+\varepsilon^{Z_{\mathrm{LS}} \mathrm{L} Z \mathrm{~S} Z \text { (grazing) }} \\
& \text { - LZ(mortality) } \\
& \frac{d Z_{\mathrm{S}}}{d t}-\frac{\partial}{\partial z}\left(A_{\mathrm{h}} \frac{\partial Z_{\mathrm{S}}}{\partial z}\right) \\
& =\varepsilon^{Z_{\mathrm{S}} \mathrm{S} Z \mathrm{~S} P(\text { grazing })}-\mathrm{LZSZ}(\text { grazing }) \\
& +\varepsilon^{B} \mathrm{~S} Z B(\text { grazing })-\mathrm{S} Z \text { (mortality) } \\
& \frac{d B}{d t}-\frac{\partial}{\partial z}\left(A_{\mathrm{h}} \frac{\partial B}{\partial z}\right) \\
& =D B(\text { decomposition })+B P(\text { uptake }) \\
& -\mathrm{S} Z B \text { (grazing) - B(mortality) } \\
& \frac{d D}{d t}-\frac{\partial}{\partial z}\left(A_{\mathrm{h}} \frac{\partial D}{\partial z}\right) \\
& =\left(1-\varepsilon^{z_{\mathrm{L}}}\right) \mathrm{L} Z \mathrm{~L} P(\text { grazing }) \\
& +\left(1-\varepsilon^{Z_{\mathrm{S}}}\right) \mathrm{S} Z \mathrm{~S} P(\text { grazing})
\end{aligned}
$$

$$
\begin{aligned}
& +\left(1-\varepsilon^{B}\right) \mathrm{S} Z B \text { (grazing) } \\
& +\left(1-\varepsilon^{Z_{\mathrm{LS}}}\right) \mathrm{L} Z \mathrm{~S} Z \text { (grazing) } \\
& -D B(\text { decomposition })-D P(\text { sinking }) \\
& -D P(\text { remineralization })+\mathrm{L} P(\text { mortality }) \\
& +\mathrm{S} P(\text { mortality })+\mathrm{L} Z \text { (mortality }) \\
& +\mathrm{S} Z(\text { mortality })+B(\text { mortality }) \\
\frac{d P}{d t} & -\frac{\partial}{\partial z}\left(A_{\mathrm{h}} \frac{\partial P}{\partial z}\right) \\
= & -\mathrm{L} P(\text { uptake })-\mathrm{S} P(\text { uptake })-B P(\text { uptake }) \\
& +D P(\text { remineralization })+P Q
\end{aligned}
$$

where $P_{\mathrm{L}}, P_{\mathrm{S}}, Z_{\mathrm{L}}, Z_{\mathrm{S}}, B, D$ and $P$ are the large size phytoplankton, small size phytoplankton, large size zooplankton, small size zooplankton, bacteria, detritus and phosphorus, respectively. $A_{\mathrm{h}}$ is the thermal diffusion coefficient, which was calculated

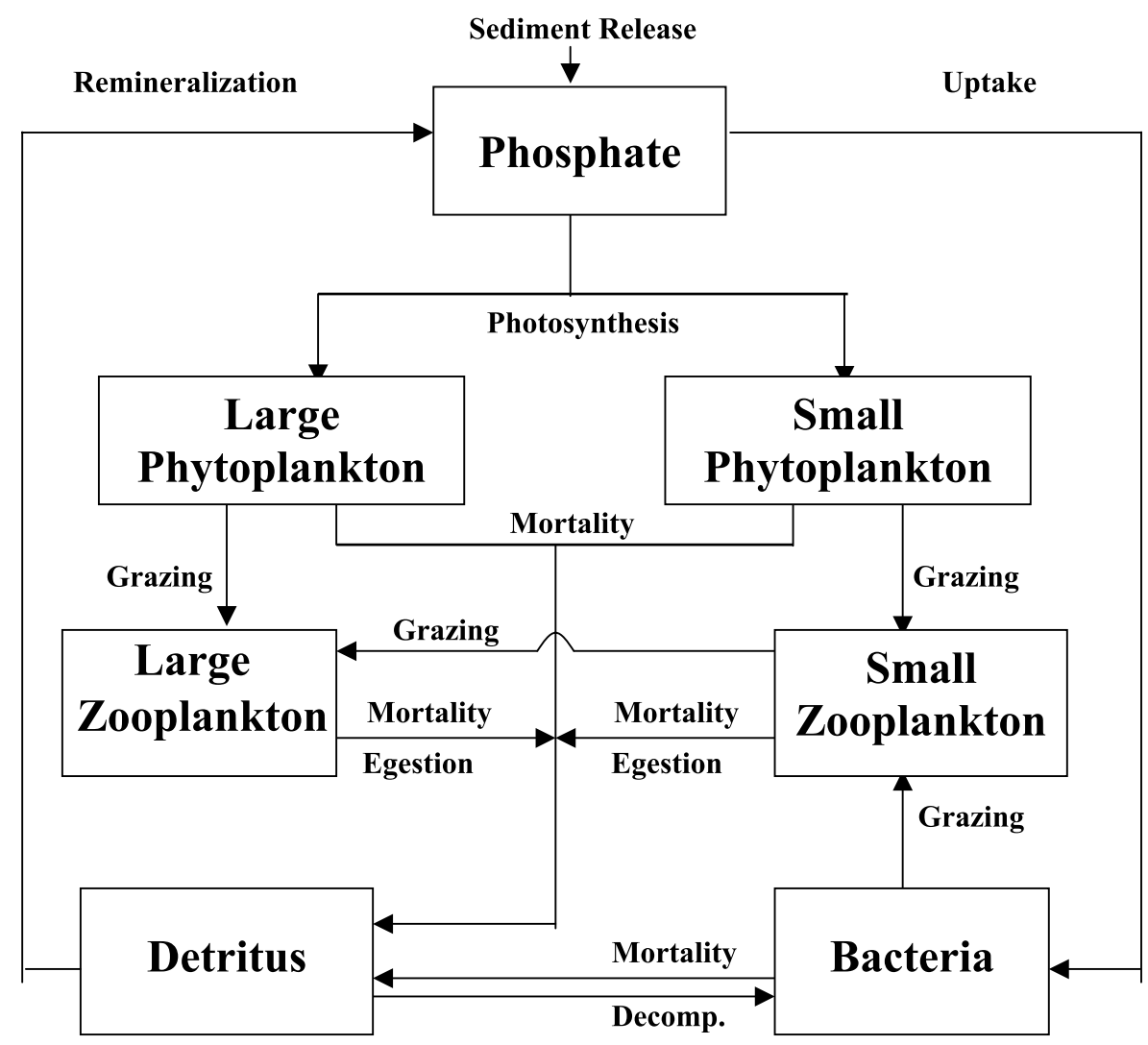

Fig. 5. Schematic of the lower trophic level food web model for Lake Michigan. 
using the Mellor and Yamada level 2.5 turbulent closure scheme incorporated in the physical model.

$\frac{d}{d t}=\frac{\partial}{\partial t}+u \frac{\partial}{\partial x}+v \frac{\partial}{\partial y}+w \frac{\partial}{\partial z}$

is the derivative operator; $x, y$ and $z$ are the eastward, northward and vertical axes of the Cartesian coordinate and $u, v$ and $w$ are the $x, y$ and $z$ components of the velocity. $P Q$ is the phosphorus release rate from suspended sediments. LP (uptake), $\mathrm{S} P$ (uptake) and $B P$ (uptake): phosphorus uptakes by large phytoplankton, small phytoplankton and bacteria, respectively; LZLP (grazing) and LZSZ (grazing): large zooplankton grazing to large phytoplankton and small zooplankton, respectively; SZSP (grazing): small zooplankton grazing to small phytoplankton; $\mathrm{S} Z B$ (grazing): small zooplankton grazing to bacteria; $D B$ (decomposition): detritus decomposition to bacteria; $D P$ (remineralization): detritus remineralization to phosphorus. LP (sinking), $\mathrm{S} P$ (sinking) and $D P$ (sinking): large phytoplankton, small phytoplankton and detritus sinking fluxes; L $P$ (mortality), SP (mortality), $\mathrm{L} Z$ (mortality), $\mathrm{S} Z$ (mortality) and $B$ (mortality): the mortality of large and small phytoplanktons, large and small zooplanktons, and bacteria, respectively. $\varepsilon^{Z_{\mathrm{L}}}, \varepsilon^{Z_{\mathrm{s}}}, \varepsilon^{B}$ and $\varepsilon^{Z_{\mathrm{LS}}}$ are the assimilation efficiency of large zooplankton on large phytoplankton, small zooplankton on small phytoplankton, small zooplankton on bacteria and large zooplankton on small zooplankton, respectively. The definition of each specific term in Eqs. (1)-(7) and parameters used in this study were the same as those shown in Chen et al. (2002).

The physical model used in this study was the Princeton ocean model (POM) developed originally by Blumberg and Mellor (1987). The POM has been configured for Lake Michigan geometry (Schwab et al., 2000; Beletsky et al., 2000), with a uniform grid size of $2 \mathrm{~km}$ in the horizontal and $21-\sigma$ levels in the vertical (Fig. 4).

The 3-D numerical experiments were focused on the spring 1998 plume event. The coupled biological and physical model was forced by realistic winds and surface heat fluxes. It was spun up over 2 months, starting on January 1, 1998 and the model results from March 1 to 31, 1998 were output for model-data comparisons. The initial temperature was specified to be $2{ }^{\circ} \mathrm{C}$ everywhere in the lake, which was close to the climatologically averaged temperature value in January. The initial biological field was specified according to the data obtained from a comprehensive survey taken on January 28 1998, which showed a relatively homogeneous distribution of the biological variables in the lake. The initial values of $P, P_{\mathrm{L}}, P_{\mathrm{S}}, Z_{\mathrm{L}}, Z_{\mathrm{S}}, B$ and $D$ were given as $0.01 \mu \mathrm{mol} P 1^{-1}$ and 1.6, 1.6, 2.0, 0.5, 3.0 and $7.7 \mu \mathrm{mol} C 1^{-1}$, respectively.

Two key issues must be addressed in order to examine the impact of suspended sediment on the ecosystem in Lake Michigan. One is how to estimate the suspended sediment concentration in the water column and another is to determine the light attenuation coefficient when the suspended sediment exists. In March 1998, the cloud-free Rrs(555) imageries were available almost daily in Lake Michigan. These RSR imagery data were coherent well with suspended sediment water samples taken on St. Joseph, Muskegon, Gary and Chicago transects during the March 1998 interdisciplinary cruise, and a regression relationship between RSR and observed surface suspended sediment concentration $C_{\mathrm{s}}(x, y, t)$ is given as

$C_{S}(x, y, t)=1.0888 \mathrm{e}^{84.739 \mathrm{RSR}(x, y, t)}$

and the S.D. of this fitting is $\hat{\sigma}= \pm 1.74$ (Fig. 6 : upper panel). Using this function, the $\operatorname{Rrs}(555)$ data were converted to the surface sediment concentration with a time interval of 1 day. Since the water was vertically well mixed during the plume event, it is reasonable to specify the $3-\mathrm{D}$ distribution of the suspended sediment used for the model run by the surface sediment concentration converted from the $\operatorname{Rrs}(555)$.

The observations, which were taken at ten sites on St. Joseph, Muskegon, Gary and Chicago transects, show a linear relationship between sediment concentration and light attenuation coefficient $\left(k_{\text {ext }}\right)$ (Fig. 6: lower panel). Within a S.D. of $\hat{\sigma}=0.01, k_{\text {ext }}(x, y, t)$ can be expressed as

$k_{\text {ext }}(x, y, t)=0.742 C_{\mathrm{s}}(x, y, t)+0.1786$

In our numerical experiments, we assumed that the impact of suspended sediments on the lower trophic level food web system in Lake Michigan was mainly through two channels. One was to increase the downward light attenuation coeffi- 

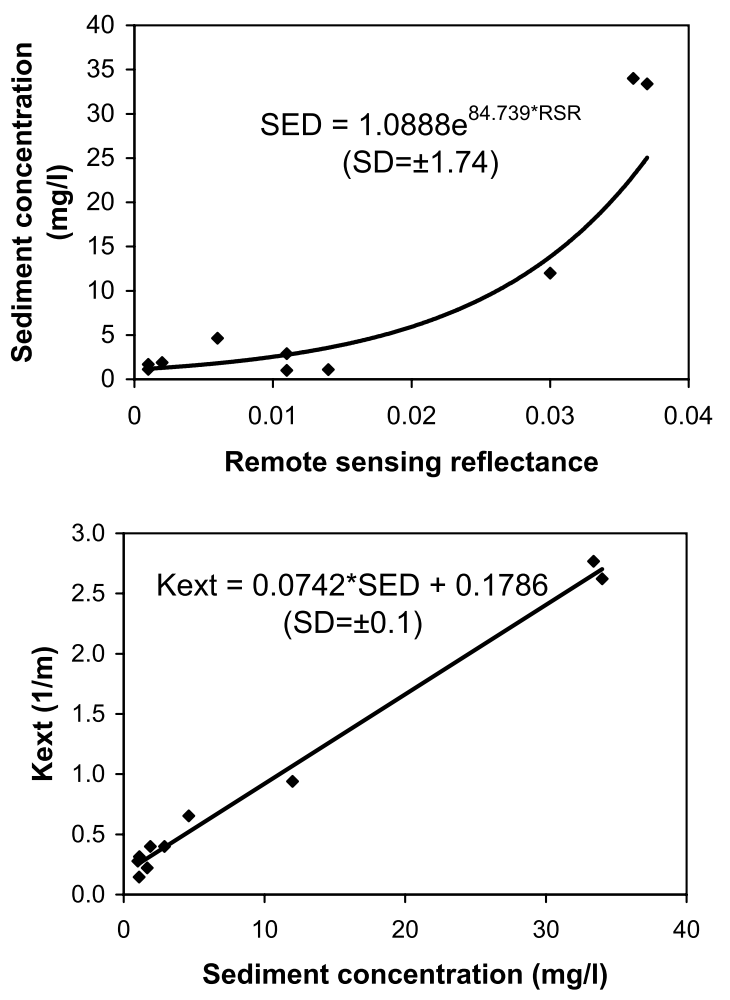

Fig. 6. The regression fittings of sediment concentration with respect to remote-sensing reflectance (upper) and light attenuation coefficient with respect to sediment concentration (below). Filled squares represent the water samples taken during the March 1998 interdisciplinary plume cruise.

cient and another was to release nutrients. $k_{\text {ext }}$ $(x, y, t)$ at each grid point for each time step was calculated using Eq. (9), in which the $\operatorname{Rrs}(555)$ derived sediment concentration $C_{\mathrm{s}}(x, y, t)$ estimated using Eq. (8) was interpolated spatially and temporally to grid points and time steps. No data were available for the phosphate release rate from suspended sediments in previous measurements in Lake Michigan. A single rate of $0.5 \times 10^{-3} \mu \mathrm{mol}$ $P \mathrm{mg}^{-1}$ per day was specified in the model run for the purpose of process studies, with the understanding that in the real world the release process might be much more complex. Several numerical experiments with and without nutrient releases from suspended sediments were conducted later to evaluate the importance of the nutrient releases in maintaining the nutrient level in Lake Michigan.
Discharges from 18 rivers flowing into Lake Michigan and two outflows were also included in the numerical experiments. River discharge rates at each river are listed in Table 1 . These rates were based upon long-term flow data from the USGS and Great Lake Basin Commission reports (Upchurch, 1976; Robertson, 1996). Two adjustments were made to the data: (1) flow contributions from small (yet flow-monitored) streams were added to the nearest major river; and (2) the long-term mean flows were adjusted to obtain a hydraulic (volumetric) balance with the Strait of Mackinaw outflow.

To examine the impact of river discharges on the level of nutrients in Lake Michigan, we conducted several experiments with and without nutrient fluxes from rivers. In the two cases with river nutrient fluxes, the phosphate concentration of river water was assumed to be 0.1 and $0.2 \mu \mathrm{mol}$ $P 1^{-1}$, respectively for all the rivers.

Table 1

River discharge along Lake Michigan

\begin{tabular}{lr}
\hline River & Rate of discharge $\left(\mathrm{m}^{3} \mathrm{~s}^{-1}\right)$ \\
\hline Escanaba & 35 \\
-Ford & 16 \\
-Menominee & 147 \\
Peshtigo & 36 \\
-Oconto & 24 \\
-Fox & 210 \\
-Sheboygan & 10 \\
& \\
Manitowoc & 14 \\
-Milwaukee & 18 \\
-Chicago S\&S canal & -93 \\
-Calumet & 30 \\
-St. Joseph & 144 \\
-Paw Paw & 16 \\
-Kalamazoo & 62 \\
-Grand & 159 \\
-Muskegon & 87 \\
-Pere Marquette & 26 \\
-Manistee & 88 \\
-Boardman & 8 \\
-Manistique & 57 \\
-Strait of Mackinac & 1059 \\
\hline
\end{tabular}




\section{Model results}

All the model runs were conducted under the same physical conditions. The standard model run, which was used in all the data-model comparisons, was the case with nutrient releases from suspended sediment, but no nutrient fluxes from rivers. Several additional model runs were carried out by either excluding the nutrient release from suspended sediments or adding the river nutrient fluxes to explore the physical and biological mechanism responsible for maintaining the nutrient level in Lake Michigan during the plume event.

\subsection{Physical fields}

The spatial distribution and temporal variation of water circulation in southern Lake Michigan during March 1998 were mainly driven by the wind stress associated with two northerly wind events and two southerly wind events (Fig. 7). On March 9, the strong northerly wind caused relatively strong nearshore southward flows on both the eastern and western sides of the lake. These flows converged on the southeast coast near the St. Joseph, causing an outflow into the interior and forming a cyclonic circulation gyre in the southern part of the lake. A strong southward flow was also found in the center region of the northern part of southern Lake Michigan. This flow split into two branches: one moved southwestward to join the nearshore southward flow and another turned counterclockwise and met the nearshore southward flow on the eastern coast to form another cyclonic circulation in the northeastern region of southern Lake Michigan. At that time, three different offshore flow paths existed: the first was near St. Joseph, the second was between Grand Haven and South Haven and the third, near Muskegon. A southerly wind prevailed in southern Lake Michigan during March 12-13, 1998. On March 15, the second day after the northerly wind reoccurred, the pattern of water circulation was similar to that found on March 9, but the current speed was significantly reduced. The circulation pattern was significantly changed by northeasterly wind on March 20 and showed a strong flow toward the western coast and a signifi- cant offshore flow along the eastern coast in the surface layer in southern Lake Michigan. When the southerly wind prevailed over the lake on March 25, the nearshore currents reversed and flowed northward on both the eastern and western coasts, forming an anticyclonic gyre in the northern region and a cyclonic gyre in the southern region of southern Lake Michigan. The current speeds during this southerly wind event were much weaker than those during the northerly wind event occurring on March 10 because the winds were significantly weaker.

Temperature fields were characterized by two cold bands along both the eastern and western sides of southern Lake Michigan on March 10, when the northerly wind prevailed. These two cold bands were intensified on March 15, especially the one on the western side. A stronger northeasterly wind also tended to make the western side colder on March 20 and the whole lake warmed up when southerly wind prevailed on March 25. Since the heat flux was relatively uniform in southern Lake Michigan during that period, shallow regions tended to warm more rapidly than deeper regions, resulting in the nearshore banded pattern.

Spatial distribution of the circulation and temperature in the southern Lake Michigan was consistent with the wind-induced lake circulation pattern suggested by Csanady (1982). The physical explanation of the formation and evolution of this circulation is given in details in Schwab et al. (2000) and Beletsky et al. (2000).

\subsection{Biological fields}

Phosphate remained relatively uniform on March 10 before the plume occurred and exhibited a high concentration zone around the coast between Muskegon and Chicago on March 15 after the plume appeared. This high phosphate concentration zone intensified considerably after March 20 as the plume was enhanced (Fig. 8: first row). The spatial uniform distribution of phosphate prior to March 10 implied that it was apparently unaffected by the wind-induced mixing and currents before the plume appeared. 
Temperature $\left({ }^{\circ} \mathrm{C}\right)$

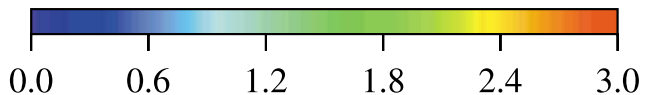

$\longrightarrow \quad 20 \mathrm{~cm} / \mathrm{s}$
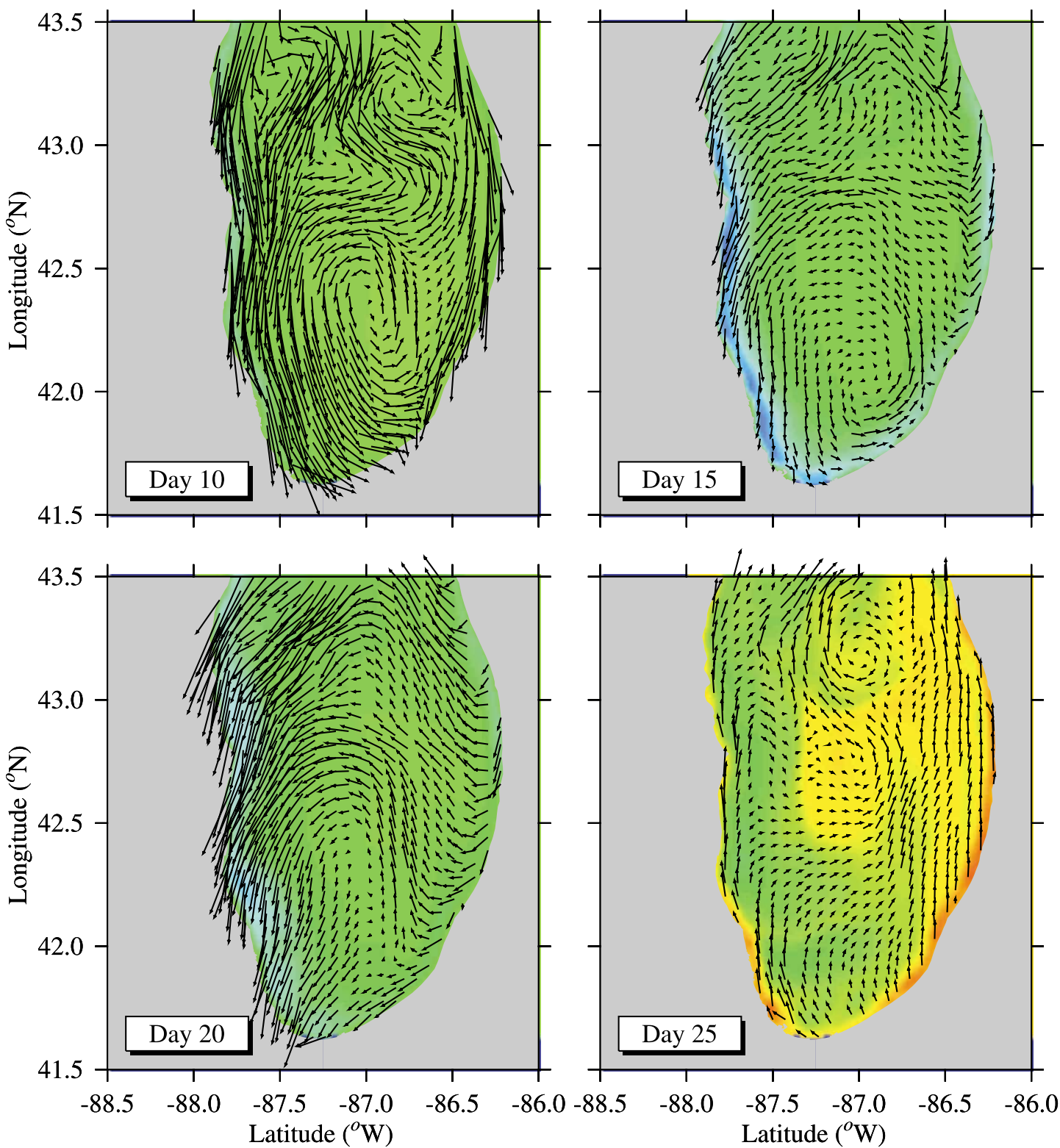

Fig. 7. Distributions of surface water current vectors and temperature in southern Lake Michigan on March 10, 15, 20 and 25, respectively. 


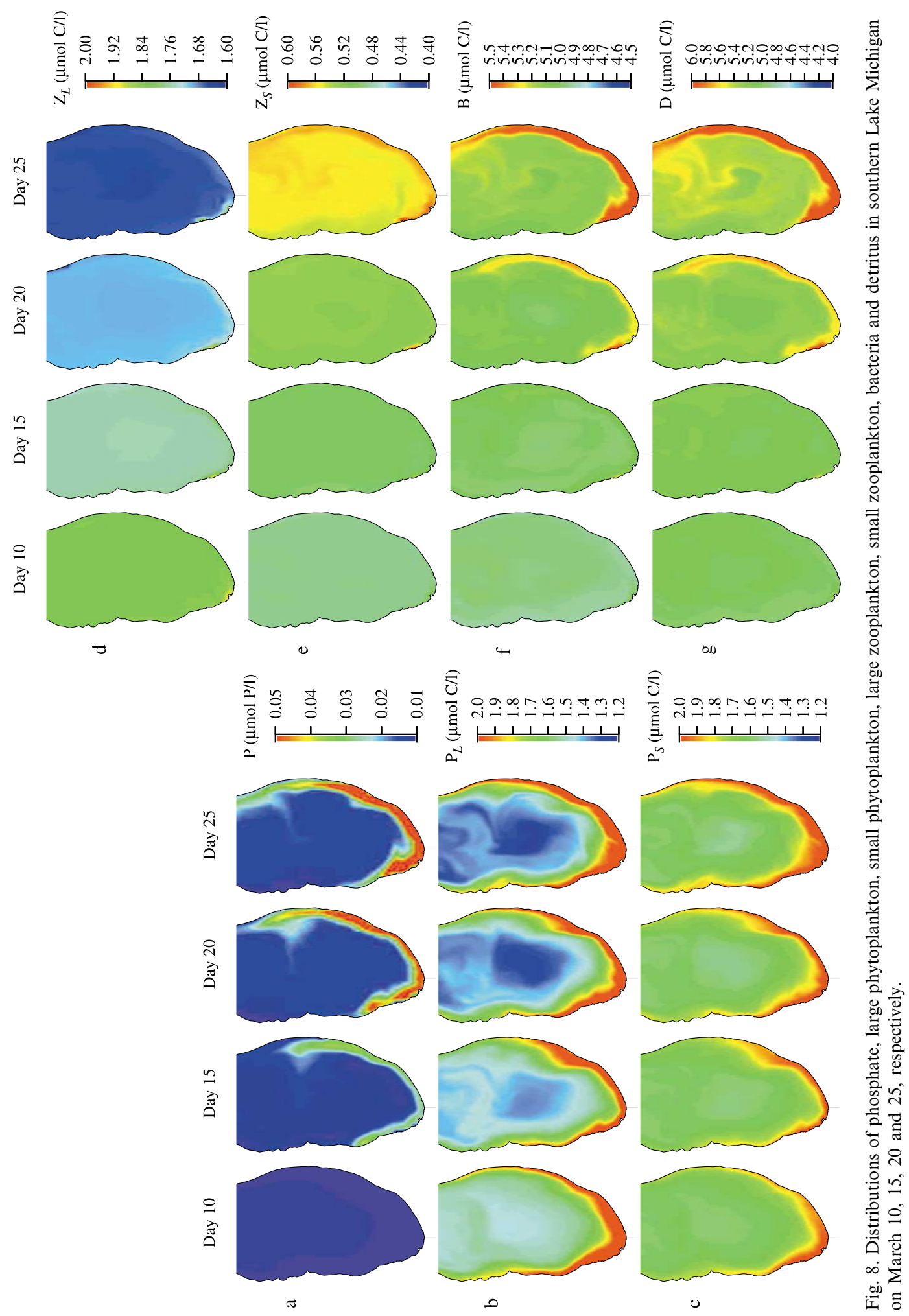


Unlike phosphate, the phytoplankton concentration showed a remarkable cross-shore distribution on March 10, highest near the coast and lowest in the interior. This pattern changed little during the rest of March after the plume appeared, except the large phytoplankton concentration in the interior dropped significantly as the plume developed (Fig. 8: second row). A wider zone with high large phytoplankton concentration was found in the southern end of Lake Michigan on March 10, the result of a strong wind-induced southward flow toward the coast. The offshore protrusion of high large phytoplankton concentration near St. Joseph found on March 15 was consistent with a significant offshore flow predicted in that area. Similar coherence was also found between the spatial distributions of large phytoplankton concentration and surface water currents on 20 and 25 March.

Spatial distribution and temporal variation of small phytoplankton concentration were very similar to those of large phytoplankton concentration, except that the concentration of small phytoplankton was relatively uniform in the interior region deeper than $40 \mathrm{~m}$ (Fig. 8: third row). The modelpredicted distribution of large zooplankton was homogeneous in March 1998, with concentration decreasing with time after the plume appeared (Fig. 8: fourth row).

The growth of small zooplankton exhibited a close dependence on bacteria and detritus (Fig. 8: fifth row). On March 10 through 15, the small zooplankton concentration remained little changed and its distribution was uniform in the entire southern Lake Michigan. These patterns matched well with the homogeneous distributions of bacteria and detritus in that area during that period (Fig. 8: sixth and seventh rows). On March 20, the detritus increased dramatically along the eastern and southern coast, with a maximum concentration in the nearshore region shallower than $20 \mathrm{~m}$ and a sub-maximum around the $120-\mathrm{m}$ isobath, forming a donut-like structure in the interior. This pattern was significantly enhanced on March 25, at which the maximum concentration around the coast exceeded $6 \mu \mathrm{mol} C 1^{-1}$ and its area expanded offshore to the $30-\mathrm{m}$ isobath. Most of the interior region was filled with detritus at a concentration level of 5.0 $\mu \mathrm{mol} C 1^{-1}$ or higher. Correspondingly, a very similar pattern was also found in bacteria and thus, in small zooplankton. The growth of small zooplankton seemed almost independent of phosphate concentration. A relatively high phosphate concentration zone was found along the eastern and southern coast between Muskegon and Chicago on March 15 after the plume appeared, but small zooplankton concentration still remained uniform in space and little change in biomass from that found on March 10 before the plume occurred. This suggests that the small zooplankton responded more favorably to the microbial loop than to small phytoplankton.

\subsection{Model-data comparison}

The model-predicted total phytoplankton concentration (a sum of small and large phytoplankton concentration) was directly compared with the chlorophyll- $a$ concentration obtained from water samples, remote-sensing and PSS on the three cross-shelf transects at Gary, St. Joseph and Muskegon, St. Joseph (Fig. 9). To make the discussion easier, we divided each transect into three zones: (1) plume zone (PZ), (2) plume edge (PE) and (3) interior region (IR). The water samples were collected on different days on the three transects: March 16 on the St. Joseph transect, March 17 on the Gary transect and March 19 on the Muskegon transect. On each transect when the water samples were taken, the PSS recorded continuously. These direct measurement data were compared with the model-predicted and satellite-derived chlorophyll- $a$ concentrations. On the Gary transect, the water samples, PSS, remote-sensing and model showed no significant cross-plume gradient of chlorophyll$a$ concentration, even though their values did not match each other. A similar cross-plume structure was also found on the St. Joseph transect, except at a near-coastal station where the concentration derived from the model, PSS and remote-sensing was $\approx 66 \%$ smaller than the water sample. On the Muskegon transect, both the model and PSSderived concentrations were relatively flat across the plume, but the water sample recorded a relatively high value of $2.7 \mu \mathrm{g}^{-1}$ at the inner edge of the plume, which was $\approx 1 \mu \mathrm{g}^{-1}$ larger than that derived by the model, remote-sensing and PSS. In 
addition, the remote sensing showed a relatively large gradient in the chlorophyll- $a$ concentration at the outer edge of the plume, which was not captured by both the PSS and model.

A similar comparison was also made between the model-predicted and observed phosphates on the three transects (Fig. 10: left panel). Except in the interior region on the Muskegon transect, the model-predicted phosphate was in reasonable agreement with the water sample data taken on these transects. Note that the model-predicted phosphate concentration was calculated with in- clusion of the nutrient released from suspended sediments, but not from river flux. Adding river phosphate flux with a concentration value of 0.1 $\mu \mathrm{mol} 1^{-1}$ into the phosphate equation, the modelpredicted phosphate concentration inside the plume on the Gary transect increased from 0.04 to $0.06 \mu \mathrm{mol} 1^{-1}$, which was $0.01 \mu \mathrm{mol} 1^{-1}$ larger than the water sample. The model-predicted phosphate concentration in the plume on the St. Joseph and Muskegon transects showed no significant difference after the river phosphate flux was added. The response of the model to the river

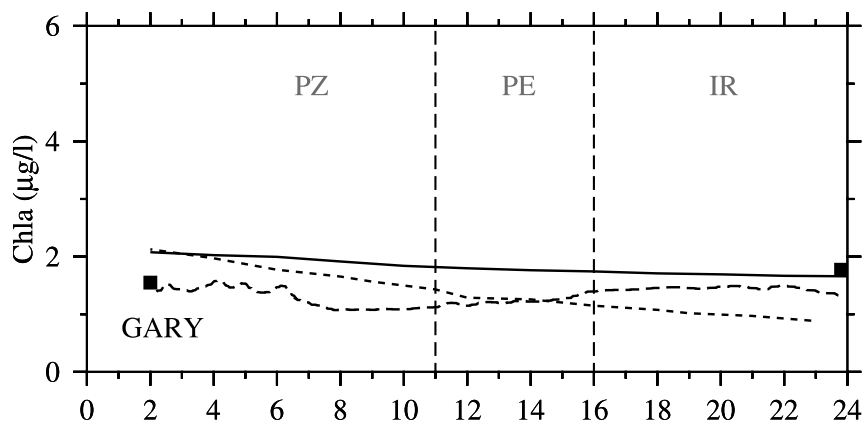

--- PSS data

- Model result
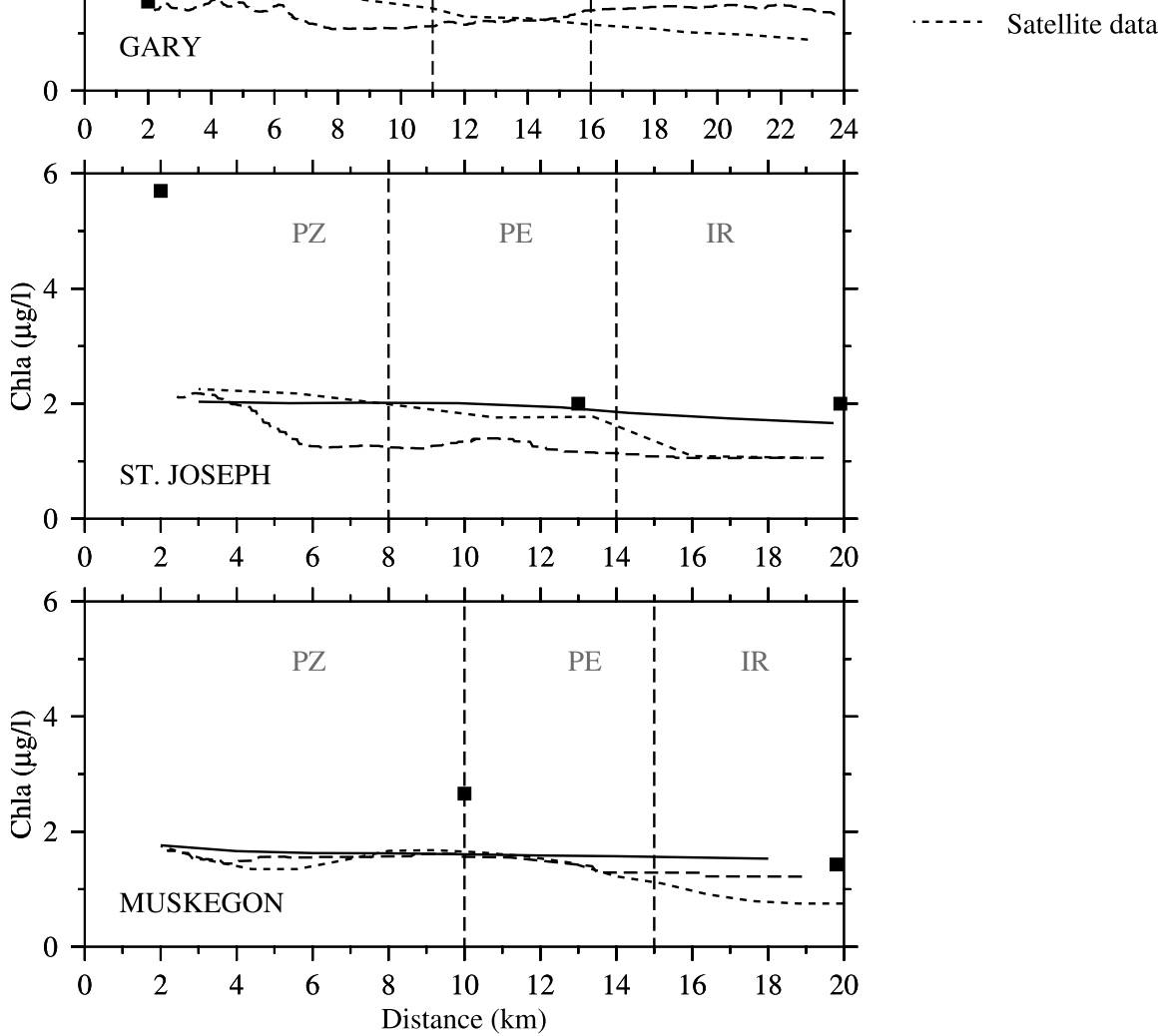

Fig. 9. Comparison of chlorophyll- $a$ concentrations derived from model prediction, remote sensing, PSS and water samples on the Gary, St. Joseph, Muskegon transects in southern Lake Michigan. 

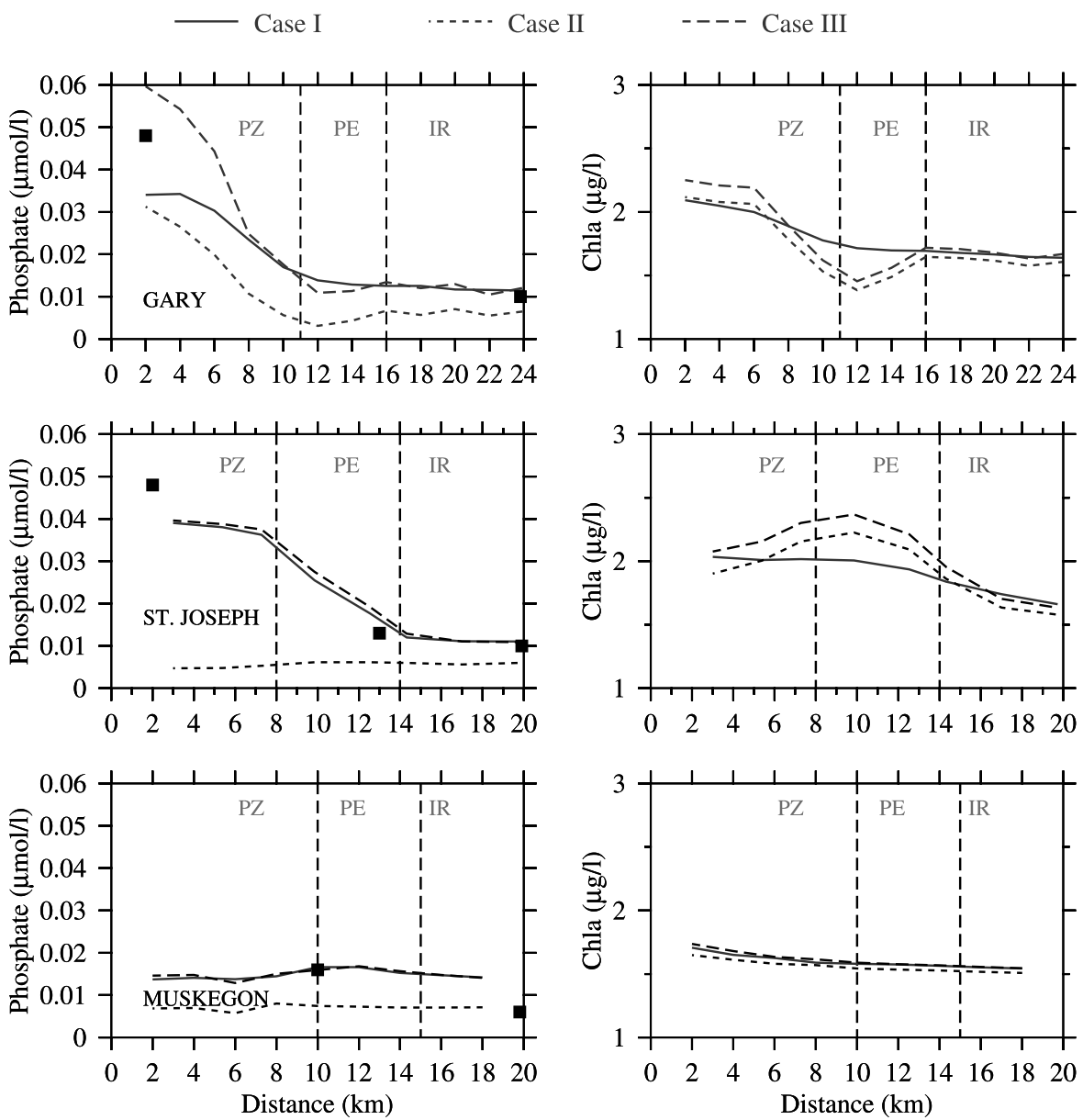

Fig. 10. Cross-shore distributions of phosphate (left) and chlorophyll- $a$ (right) concentrations for the three different cases with (1) nutrients released from suspended sediment, but no river nutrient flux; (2) nutrient released from suspended sediments plus river nutrient flux; and (3) river nutrient flux, but no nutrient released from suspended sediments.

phosphate flux was closely related to the flow field. It was large near Gary, where convergent flow was predicted in mid-March 1998 during which the water sample was collected, while it was small near St. Joseph and Muskegon, where offshore divergent flow was predicted.

Retaining the river phosphate fluxes, but removing the nutrient released from suspended sediments, significantly reduced the nutrient level in the coastal region of southern Lake Michigan. On the Gary transect, for example, the model-predicted phosphate concentration in this case was considerably underestimated within and at the edge of the plume. On the St. Joseph transect, the model-pre- dicted phosphate concentration was about five times smaller than the water sample within the plume and also showed no difference along the transect. A large disparity was also found on the Muskegon transect, suggesting that the nutrient release from suspended sediment played an important role in maintaining the phosphate level in southern Lake Michigan during the plume event. This finding supports the argument that a large portion of the net increment of phosphorus in southern Lake Michigan is due to nutrient releases from suspended sediment and internal recycling associated with the springtime suspended plume (Eadie et al., 1984; Johengen et al., 1994). 
The response of chlorophyll- $a$ concentration to the river phosphate flux significantly depends on location (Fig. 10: right panel). On the St. Joseph transect, for example, the river phosphate flux showed little impact on the phosphate concentration in the plume and hence on the chlorophyll- $a$ concentration there, although the chlorophyll- $a$ concentrations were higher at the edge of the plume. On the Muskegon transect, the model-predicted chlorophyll- $a$ concentration remained almost unchanged as either the river phosphate flux was included or the phosphate releases from suspended sediment were removed.

These numerical experiments suggest that a high chlorophyll- $a$ concentration recorded near the coast on the St. Joseph transect (observed from water samples) was probably a result of direct river output of phytoplankton that was not included in the model. In addition, the water sample at the inner edge of the plume on the Muskegon transect was collected at a depth of 5 $\mathrm{m}$ below the surface at 15:46 h on March 19, which was optimal both temporally and spatially for maximum photosynthesis to occur. The remarkable difference between model-predicted and observed chlorophyll- $a$ concentration at that site was probably due to the daily variation of photosynthesis that was not taken into account in the model experiments.

Model-predicted spatial distribution of chlorophyll- $a$ concentration was also in reasonable agreement with the satellite-derived chlorophyll- $a$ concentration. The satellite-derived chlorophyll- $a$ concentration received on March 25 showed a donut-like distribution pattern in the interior of southern Lake Michigan (Fig. 3). The high concentration zone extended offshore near the Grand Haven and appeared to circulate cyclonically in the interior. A donut-like structure of chlorophyll$a$ concentration formed just a little way offshore from the plume area. This spatial distribution was captured in the model-predicted distribution of large phytoplankton on March 25, which also showed an offshore extension in its concentration around the Grand Haven, an immediate high concentration zone following a cyclonic circulation gyre and a lower concentration in the center (Fig. 8: first row). Unlike the satellite image, our model did not capture the lower concentration band on the western side and southern end. This was probably due to several reasons associated with numerical resolution, nutrient uptake rate and vertical mixing parameter used in the model. The model was configured with a horizontal resolution of $2 \mathrm{~km}$, which was probably insufficient to resolve such a narrow band. Moreover, the nutrient uptake rate was assumed to be constant. This simple assumption ignored the temporal and spatial variation of the uptake, which was probably attributed to relatively uniform distribution of phytoplankton concentration around the western coast.

Vertical mixing was parameterized using the Mellor and Yamada level 2.5 turbulent closure model. This model was verified quantitatively for the coastal ocean, but few model-data comparisons have been made for a freshwater lake. It is questionable whether or not this turbulent model caused an over-estimation of vertical mixing in Lake Michigan. If this is the case, then the donutlike pattern of phytoplankton concentration was probably numerically smoothed by the model. Furthermore, a recent cross-lake transect survey involving CTD profiles at $1 \mathrm{~km}$ intervals from Grand Haven, Michigan to Waukegon, IL in spring 2001 show clear evidence of the donutshaped pattern of chlorophyll- $a$ concentration in that region (personal communication with Dr S.A. Green and Dr J.W. Budd, Michigan Technological University). This makes us believe that the satellite-derived donut-shaped distribution of chlorophyll- $a$ concentration is a real plankton feature in Lake Michigan.

The existence of the donut-shaped chlorophyll$a$ structure was consistent with spatial distribution of the model-predicted circulation. On March 20, before the donut feature formed, the current showed a strong offshore water transport from the eastern coast into the interior. On March 25, a remarkable offshore flow still existed around the Grand Haven, forming two circulation gyres in the interior region: cyclonic in the south and anticyclonic in the north (Fig. 7). Correspondingly, the warm water was advected offshore around the Grand Haven and formed a warm core inside the cyclonic gyre, which was very 
similar to the spatial distribution of the satellitederived chlorophyll- $a$ concentration detected on March 25. This suggests that the donut-like distribution of the chlorophyll- $a$ concentration in the interior was probably caused by the advective water transport of the wind-induced circulation.

\subsection{Cross-shore fluxes of nutrients and phytoplankton}

One of the interesting questions in the study of the ecosystem dynamics in southern Lake Michigan is to estimate the offshore fluxes of biological variables across the plume. Since the intensity of the plume varied with the magnitude and direction of the wind, the cross-plume biological fluxes were also expected to vary with the wind during the plume event. Fig. 11 shows the time sequence of the cross-shore flux of phosphate and chlorophyll- $a$ concentrations on the 20-m isobath around the southern shore of Lake Michigan. A coherent relationship was found between these

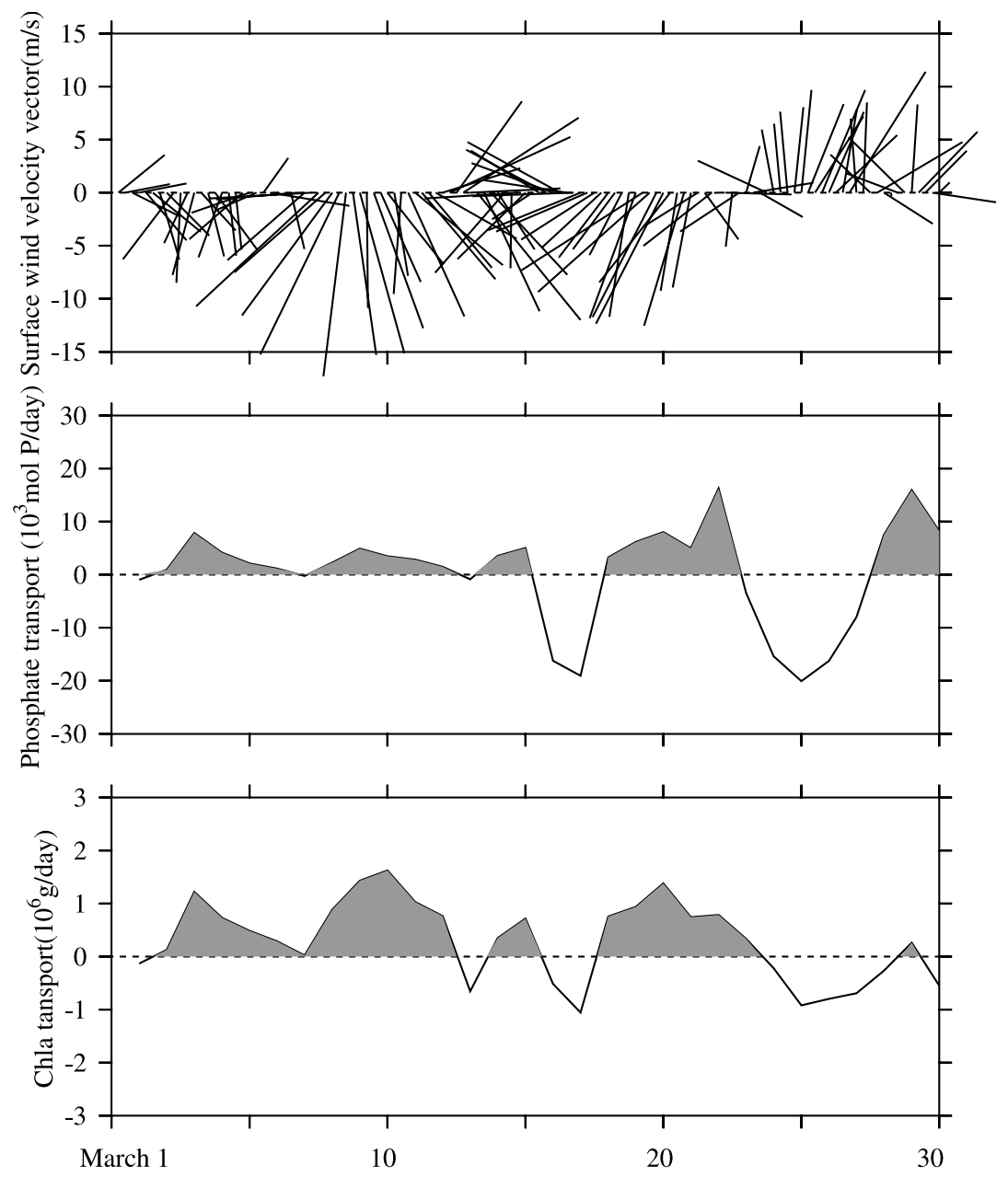

Time(Day)

Fig. 11. Time series of surface wind velocity vectors (upper) and cross-plume fluxes of phosphate (middle) and chlorophyll- $a$ (below) around the 20-m isobath during March, 1998. Positive: offshore flux and negative: onshore flux. 


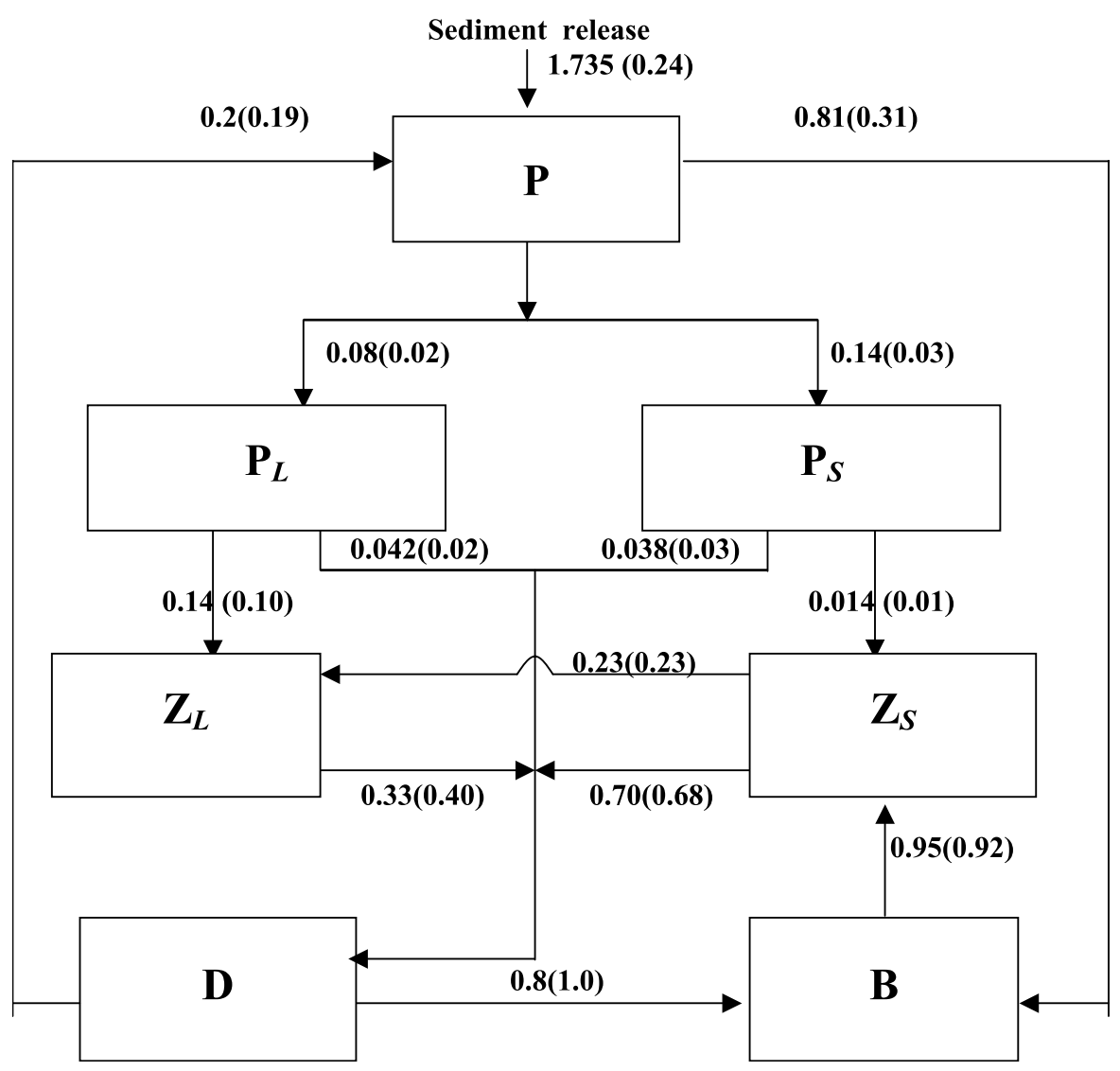

Fig. 12. The model-predicted fluxes of biological variables among the food web inside and outside the plume. The flux outside the plume is written in brackets. The flux unite was $\left(10^{-3} \mu \mathrm{mol} 1^{-1}\right.$ per day).

fluxes and wind direction: offshore during the southward wind and onshore during the northward wind. These fluxes increased with the wind speed, with a similar temporal variation scale as the wind. An exception was recorded at the end of March, when a relatively significant variance occurred in the wind direction, during which phosphate flux was offshore when the wind was northward.

\subsection{Flux within the food web}

Following the approach used in Chen et al. (2002), we also estimated the flux of biological variables within the food web inside and outside the plume. The estimation was made at sites A and B (see Fig. 1) on March 15, 1998 (Fig. 12). In this food web system, the phosphate was mainly maintained through two processes: one was phosphate release from suspended sediments (external loading) and another was from the detritus remineralization (internal recycling). The external loading was dominant within the plume, but it was comparable with the internal recycling out of the plume. Inside and outside the plume, the sum of the phosphate uptake flux by small and large phytoplankton was almost one order of magnitude smaller than the phosphate uptake flux by bacteria. In addition, large grazing fluxes were found from bacteria to small zooplankton and from small zooplankton to large zooplankton compared with the fluxes from small phytoplankton to small zooplankton and from large phyto- 
plankton to large zooplankton. This suggests that the microbial loop associated with bacteria played an important role in the balance of the lower trophic level food web system in southern Lake Michigan. This finding was consistent with the 1-D coupled biological and physical modeling experiments conducted by Chen et al. (2002), even when the suspended sediments were taken into account.

The importance of bacteria in the food web balance in a fresh water system has been suggested in many previous field and laboratory experiments. Dissolved inorganic phosphorus (DIP) and dissolved organic phosphorus (DOP) are two major nutrient sources for bacteria. In a freshwater lake system, the growth of bacteria could be restricted by DIP supply (Toolan et al., 1991; Conveney and Wetzel, 1992; Morris and Lewis, 1992) and also the bacteria could compete with phytoplankton in the DIP uptake (Currie and Kalff, 1984a; Currie and Kalff, 1984b; Cotner and Wetzel, 1992; Vadstein et al., 1993). A large DIP flux to bacteria was found in our 3-D numerical experiments, which was consistent with these previous observational results. It was not surprising to see little difference in the $D \rightarrow B$ flux and a big difference in the $P \rightarrow B$ flux inside and outside the plume (Fig. 12). In the model, the detrital pool was mainly supported by the internal cycling of the food web, with no direct connection to the suspended sediments. Therefore, since the mortality of bacteria increased as the decomposition rate from detritus to bacteria increased, the net flux changed only slightly when the suspended sediment was included. This also indirectly suggests that the DOP in our model was not a limiting factor to control the growth of bacteria.

Cotner et al. (1999) estimated the bacterial production and biomass in the March 1998 plume event in southern Lake Michigan. They found that the bacterial productivity in the plume was very large, which was comparable to that found in summer. Based on the active growth of the bacteria in the plume compared with phytoplankton, they suggest that the bacterial production in late winter through late spring before stratification develops may be temporally de-coupled from primary productivity.
Our model experiments show that no matter whether it is inside or outside the plume, the dissolved organic matters (DOM) from mortality and excretion of phytoplanktons are very small compared to those from zooplankton. This means that the growth of bacteria in southern Lake Michigan in the springtime was mainly controlled by two processes: one was the uptake of phosphate from the water column and the other was decomposition from the detrital pool, which was dominated by the mortality and excretion of zooplankton. Therefore, the microbial food web system could be de-coupled from phytoplankton, which is consistent with suggestions from the field measurements.

In addition, the model-predicted large grazing flux from bacteria to small zooplankton was consistent with previous measurements taken in Lake Michigan. Scavia and Laird (1987) reported that the growth of microzooplankton in southern Lake Michigan was mainly supported by bacteria, which is what we found from the model.

\section{Discussion}

One of the interesting phenomena found in this modeling experiment is that the offshore decrease of the large phytoplankton concentration was very similar before and after the plume occurred. Sverdrup (1953) pointed out that in the open ocean, the temporal distribution of phytoplankton is controlled by the ratio of the euphotic depth to the mixed layer depth. This theory is also applied to Lake Michigan. Let us define $D\left[I_{\mathrm{e}}(x, y, t)\right]$ as the euphotic depth at which the light intensity was $1 \%$ of that at the surface, $H(x, y)$ as the local water depth and $R$ as the ratio of these two variables, i.e.

$R=D\left[I_{\mathrm{e}}(x, y, t)\right] / H(x, y)$

The phytoplankton concentration decreases with a decrease of $R$. This can be easily interpreted as follows. Before the plume appeared, the light attenuation coefficient was approximately constant with a value of $0.1786 \mathrm{~m}^{-1}$ (see Eq. (9)) and thus the euphotic depth was constant across the lake. Since the phosphate was spatially uni- 
form at that time, the model-predicted growth of large phytoplankton was the same everywhere in southern Lake Michigan in the euphotic zone. However, strong wind mixing caused the large phytoplankton to be distributed equally in the vertical water column, leading to the offshore decrease in large phytoplankton abundance in southern Lake Michigan. After the plume occurred, since the light attenuation coefficient varied with the spatial distribution of suspended sediment concentration, the euphotic depth was a function of space and time, which was generally smaller inside than outside the plume. Inside the plume, the growth of the phytoplankton was limited by the poor light conditions, but supported by increased phosphate availability from the nutrient release by the suspended sediment. Whereas, outside the plume it was limited by the available phosphate in the interior, but supported by better light condition. These tradeoffs between light availability and nutrient conditions have no significant effects on primary production inside and outside the plume. Because strong mixing led to a vertically uniform distribution of the phytoplankton in southern Lake Michigan in March 1998, the spatial distribution of model-predicted chlorophyll- $a$ concentration still follows $R$.

Our model reproduced the surface distribution of chlorophyll- $a$ concentration detected from the satellite images. However, it failed to capture the lower concentration band of chlorophyll- $a$ on the western side and southern end of the basin as that shown in the satellite-derived chlorophyll- $a$ concentration. We have argued that this was attributed to (1) numerical resolution; (2) constant nutrient uptake rate; and (3) vertical mixing parameterization. An alternative interpretation is given here according to the temporal and spatial distribution of detritus biomass shown in Fig. 8 . The model predicted a well-defined donut-like structure in the detritus biomass after March 20, 1998, which coincided well with the donut-like distribution of the satellite-derived chlorophyll- $a$ concentration detected during the same period. The source of the detrital pool in our model was from (1) unassimilated portions of the zooplankton grazing; and (2) dead phytoplankton, zooplankton and bacteria. If we believe the donut-like distribution of model-predicted detritus biomass, then, we could argue that the donut-like distribution of the satellite-derived chlorophyll- $a$ concentration was partially attributed to the dead tissues of the phytoplankton that was unable to be separated from the chlorophyll- $a$ estimation in the satellite data. Therefore, the direct measurements must be taken into action to verify and quantify this structure in the future.

\section{Summary}

The influence of suspended sediments on the Lake Michigan ecosystem was examined using a 3-D coupled biological and physical model. The biological model consisted of a phosphorus-controlled lower trophic level food web system with seven state variables (phosphorus, small and large phytoplankton, small and large zooplankton, bacteria and detritus). The physical model was the Princeton ocean model (POM) configured for Lake Michigan. The coupled model was forced by the 1998 real-time wind and heat flux under the wintertime climatological initial conditions. The model was run prognostically with the input of the real-time suspended sediment concentration derived directly from the remote sensing reflectance.

The model results show that the suspended sediments in the reflective, recurrent coastal plume had a significant impact on the spatial distribution and temporal variation of the nutrients and plankton in southern Michigan Lake in spring of 1998. The nutrients released from suspended sediments were critical to maintain the limited nutrient level during the plume event. The springtime growth of phytoplankton depended on the availability of nutrients and light under the plume environment, while the cross-shelf decreasing tendency of the phytoplankton concentration was mainly controlled by a ratio of the euphotic depth to the mixed layer depth.

The cross-isobath fluxes of nutrients and phytoplankton were mainly driven by episodic wind events over a period of $\approx 5-7$ days. The flux was generally offshore during southward winds and onshore during northward winds. The flux esti- 
mates among biological variables in the food web system suggested that bacteria was a main controlling factor for the growth of microzooplankton in the plume. The lower trophic level food web system in southern Lake Michigan might be divided into two decoupled loops: (1) detritusbacteria-microzooplankton-large zooplankton; and (2) nutrient-phytoplankton-detritus.

The model-predicted spatial distributions of nutrients and phytoplankton were in reasonable agreement with observations taken during the 1988 EEGLE interdisciplinary cruises and from the satellite imagery. The characteristics of the food web system revealed in our model experiments were consistent with observations made from previous field studies. All of these indicate that our model was sufficiently robust to capture the basic seasonal variation of the ecosystem in Lake Michigan.

Our modeling in Lake Michigan has provided us a higher lever of understanding on the impact of suspended sediments on the lower trophic level food web system in freshwater lakes. Numerical approaches in this work could be used to examine the ecosystem in high-turbidity coastal oceans and other freshwater lakes.

\section{Acknowledgements}

This research was supported by the NSF/ NOAA EGGLE program under NSF Grant No. OCE-9712869 for C. Chen, OCE-9712872 for J.W. Budd, NOAA Coastal Ocean program grant for D.J. Schwab, D. Beletsky, G.L. Fahnenstiel, J. Cotner, T.H. Johengen, B. Eadie, H. Vanderploeg and W. Gardner, and under NSF Grant No. OCE-9730416 for M.H. Bundy. R. Ji is supported by C. Chen's NSF grant. River discharges were provided by D. Endicott (EPA Large Lakes Research Station).

\section{References}

Beletsky, D., Schwab, D.J., McCormick, M.J., Miller, G.S., Saylor, J.H., Roebber, P.J., 2000. Hydrodynamic modeling for the 1998 Lake Michigan coastal turbidity plume event.
Proceedings of the Estuarine and Coastal Modeling Conference, American Society of Civil Engineers, November 3-5, 1999, New Orleans, LA, pp. 597-613.

Blumberg, A.F., Mellor, G.L., 1987. A description of a threedimensional coastal ocean circulation model. Coast. Estuar. Sci. 4, 1-6 In: Three-dimensional Coastal Ocean Model, N.S. Heaps (Ed.).

Budd, J.W., Warrington, D.S., Ransibrahmanakul, V., Chye, J.D., 2000. Episodic events and trophic pulses: estimating surface chlorophyll concentrations and transport using SeaWiFS imagery. Ocean Sciences Meeting, ASLO-AGU, San Antonio, TX, 24-28 January, 2000.

Budd, J.W., Yu, T., Chye, J.D., Klipp, T.A., 2001. Thermal and biological fronts in southern Lake Michigan as seen from simultaneously-acquired SeaWiFS and AVHRR imagery. Limnol. Oceanogr. (Submitted).

Chen, C., Ji, R., Schwab, D.J., Beletsky, D., Fahnenstiel, G.L., Johengen, T.H., Vanderploeg, H., Eadie, M., Jiang, B., Bundy, M., Gardner, W., Cotner, J., Lavrenty P.J., 2002. A model study of the coupled biological and physical dynamics in Lake Michigan. Ecol. Model. 152(2-3), 145168.

Conveney, M.F., Wetzel, R.G., 1992. Effects of nutrients on specific growth rate of bacterioplankton in oligotrophic lake water cultures. Appl. Environ. Microbiol. 58, 150156.

Cotner, J.B., Wetzel, R.G., 1992. Uptake of dissolved inorganic and organic phosphorus compounds by phytoplankton and bacterioplankton. Limnol. Oceanogr. 37, 232-243.

Cotner, J.B., Johengen, T.B., Biddanda, B.A., 1999. Rapid bacterial production in extremely cold waters stimulated by benthic-pelagic exchanges. ASLO Meeting, February 1-5, 1999, Santa Fe, NM.

Csanady, G.T., 1982. Circulation in the Coastal Ocean. D. Reidel, Dordrecht, Holland, Boston, Hingham, MA 264pp.

Currie, D.J., Kalff, J., 1984a. Can bacteria outcompete phytoplankton for phosphorus? A chemostat test. Microb. Ecol. 10, 205-216.

Eadie, B.J., Chambers, R.L., Gardner, W.S., Bell, G.W., 1984. Sediment trap studies in Lake Michigan: resuspension and chemical fluxes in the southern basis. J. Great Lake Res. 10, 307-321.

Eadie, B.J., Schwab, D.J., Leshkevich, G.A., Johengen, T.H., Assel, R.A., Hawley, N., Holland, R.E., Lansing, M.B., Lavrentyev, P., Miller, G.S., Morehead, N.R., Robbins, J.A., Van Hoof, P.L., 1996. Recurrent coastal plume in southern Lake Michigan. EOS 77, 337-338 (AGU weekly).

Edgington, D.N., Robbins, J.A., 1973. Determination of recent sedimentation rates in Lake Michigan using $210 \mathrm{~Pb}$ and 126Cs. Ann. Rep. Radioi, Environment Research Division, Argonne National Laboratory, ANL-8060. Part III, pp. $39-62$.

Johengen, T.H., Johannsson, O.E., Pernie, G.L., Millard, E.S., 1994. Temporal and seasonal trends in nutrient dynamics and biomass measures in Lake Michigan and Ontario in response to phosphorus control. Can. J. Fish Aquat. Sci. 51, 2570-2578. 
Lineback, J.A., Gross, D.L., Meyer, R.P., Unger, W.L., 1971. High-resolution seismic profiles and gravity cores of sediments in southern Lake Michigan. Illinois Geological Survey Environmental Geology Notes, No. 47, 41pp.

Morris, D.P., Lewis, W.M.J., 1992. Nutrient limitation of bacterioplankton growth in Lake Dillon, Colorado. Limnol. Oceanogr. 37, 1179-1192.

Mortimer, C.H., 1988. Discoveries and testable hypotheses arising from coastal zone color scanner imagery of southern Lake Michigan. Limnol. Oceanogr. 33, 203-226.

Robertson, D.M., 1996. Use of frequency-volume analyses to estimate regionalized yields and loads of sediment, phosphorus, and polychlorinated biphenyls to Lakes Michigan and Superior. USGS, Water-Resources Investigations, Report 96-4092, Madison, WI.

Scavia, D., Laird, G.A., 1987. Bacterioplankton in Lake Michigan: dynamics, controls, and significance to carbon flux. Limnol. Oceanogr. 32 (5), 1071-1133.
Schwab, D.J., 1983. Numerical simulation of low-frequency current fluctuations in Lake Michigan. J. Phys. Oceanogr. 13 (12), 2213-2224.

Schwab, D.J., Beletsky, D., Lou, J., 2000. The 1998 coastal turbidity plume in Lake Michigan. Est. Coast. Shelf Sci. $50,49-58$.

Sverdrup, H.W., 1953. On conditions for the vernal blooming of phytoplankton. J. Cons. Perm. Int. Explor. Mer. 29, $130-135$.

Toolan, T., Wehr, J.D., Findlay, S., 1991. Inorganic phosphorus stimulation of bacterioplankton production in a mesoeuphotic Lake. Appl. Environ. Microbiol. 57, 2074-2078.

Upchurch, S.B., 1976. Lake basin physiography. In: Limnology of Lakes and Embayments. Great Lakes Basin Framework Study. Appendix 4. Great Lakes Commission, Ann Arbor, MI, pp. 17-25.

Vadstein, O., Olsen, Y., Reigertsen, H., Jensen, A., 1993. The role of planktonic bacteria in phosphorus cycling in lakes — sink and link. Limnol. Oceanogr. 38, 1539-1544. 